\title{
Higher prevalence of arterial vs venous disorders in patients with congenital Prekallikrein deficiency
}

\author{
Antonio Girolami*, Silvia Ferrari and Bruno Girolami \\ Departments of Medicine, University of Padua Medical School, Padua City Hospital, Padua, Italy
}

Congenital PK deficiency is one of the contact phase defects of blood coagulation.

The other two are represented by FXII and Kininogen (K) deficiencies [1].

The condition has been drawing considerable attention during the past few years. The first review article on the subject appeared in 2010 and dealt with a literature of about 90 patients [2]. Several additional cases have been reported in the following years [3-9].

The most striking aspect of Prekallikrein (PK) deficiency consists in the discrepancy between the severe coagulation defect and the paucity of its clinical manifestations. Bleeding was occasionally reported but it seems to be unrelated to the clotting defect [2].

Patients with PK deficiency show often with hypertension and hypertension related disorders [10,11].

An evaluation of the 121 cases of PK deficiency so far reported [1,5-9] indicates that $25(20,66 \%)$ of them showed arterial diseases (hypertension or its complications) whereas only 4 (3.31\%) had venous disorders (thrombosis). The difference between arterial and venous disorders is clear and is statistically significant $(\mathrm{p}=0.01)$ (Table 1$)$. Three of the patients with Venus Thrombosis (V.T.) had also hypertension. The other had pulmonary embolism (P.E.) and an ischemic stroke $[12,13]$. The latter is the only patient who had both an arterial and a venous thrombosis [13].

The discrepancy between arterial and venous thrombosis is important since it suggests that, at least in some instances, the events may be two different conditions.

These findings are in agreement with the following observations:

1. PK deficiency is common among African Americans (AA) and apparently among Africans [14].

2. African-Americans present often hypertension and hypertension related disorders [15-17]. The same may be true for Africans but this has not been demonstrated yet.

3. PK deficiency has been less frequently demonstrated in CaucasianAmericans [14].

The main physiological roles of $\mathrm{PK}$ is to reinforce the activation of FXII and to release bradykinin from High Molecular Weight (HMW) kininogen [1].

These results indicate that the pathogenesis of thrombus formation is different in arterial and in veins. The status of the vessel wall is important in arterial diseases whereas the coagulability of blood plays a major role in venous thrombosis.
The lack of bradykinin formation due to the lack of PK seems deleterious mainly for the arterial wall function. Hypertension may occur.

Protracted hypertension leads to atherosclerosis and to arteriosclerosis. The former predisposes to atheroma formation. The atheroma may fissure or ulcerate and cause local activation of coagulation with fibrin deposition and thrombus formation. Occlusion of the arterial vessel may ensue.

Since hypertension is frequent among African Americans it is conceivable that the co-existence of PK deficiency may play a role. This is suggested by the frequent presence of PK deficiency among African Americans [14].

This observation confirms that PK acts also on the arterial wall and not only on the clotting mechanism. It is commonly accepted that arterial thrombosis is mainly associated with athero and arterialsclerosis whereas venous thrombosis is mainly dependent on blood coagulation. However, this may not be absolute since at least one patient showed both arterial and venous thrombosis [13] and in at least another family, two affected siblings presented arterial or venous thrombosis [12].

Finally, it is worth noting that 9 of these patients $(36,0 \%)$ were African-Americans (AA).

This figure is higher than expected just for this population of the USA (42 million out of 380 million) namely $11,05 \%$. Furthermore, it has to be noted that the ethnic background of USA patients with this clinical condition is not always indicated; it is likely, therefore, that the proportion of AA would be further increased [13,18-19].

The frequent presence of Prekallikrein deficiency found among African-Americans may, at least in part, justify the high prevalence of cardiovascular disorders seen in this ethnic population [15-19]. Needless to say that other factors such as diet, type of work and environment may play a role. A close relation between some PK gene polymorphisms and hypertension has been demonstrated also in other populations [20].

This observation further supports the likely role of Prekallikrein deficiency in the pathogenesis of arterial hypertension and related disorders and indicates also that venous thrombosis is rare in this defect.

${ }^{\star}$ Correspondence to: Antonio Girolami, Departments of Medicine, University of Padua Medical School, Via Ospedale, 105, Padua, 35128, Italy, Tel: 00390498213026; Fax: 0039049657391; E-mail: antonio.girolami@unipd.it

Key words: prekallikrein, arterial, venous, thrombosis

Received: November 25, 2020; Accepted: December 14, 2020; Published: December 17, 2020 
Table 1. Main features of patients with prekallikrein deficiency and venous thrombosis

\begin{tabular}{|c|c|c|c|c|c|c|c|c|}
\hline Authors (year) & $\begin{array}{l}\text { Age/ } \\
\text { gender }\end{array}$ & $\begin{array}{l}\text { PK } \\
\text { Activity } \\
(\%)\end{array}$ & $\begin{array}{l}\text { PK } \\
\text { Antigen } \\
(\%)\end{array}$ & Type of defect & $\begin{array}{l}\text { Degree of } \\
\text { hypertension }\end{array}$ & Other associated risk factors & $\begin{array}{l}\text { Complications of } \\
\text { hypertension }\end{array}$ & Comments \\
\hline $\begin{array}{l}\text { Goodnough, et al } \\
1988(12) \\
\text { Case } 1 \\
\text { Case } 2 \\
\text { Case } 3\end{array}$ & $\begin{array}{l}\text { M, } 42 \\
\text { F, 36 } \\
\text { F, } 44\end{array}$ & $\begin{array}{l}1 \\
1 \\
1\end{array}$ & $\begin{array}{l}\text { Absent } \\
\text { Absent } \\
\text { Absent }\end{array}$ & $\begin{array}{l}\text { Probably Hom. } \\
\text { Same } \\
\text { Same }\end{array}$ & $\begin{array}{l}\text { n.r. } \\
\text { n.r. } \\
\text { n.r. }\end{array}$ & $\begin{array}{l}\text { none } \\
\text { obesity } \\
\text { obesity }\end{array}$ & $\begin{array}{l}\text { Stroke } \\
\text { n.r. } \\
\text { n.r. }\end{array}$ & $\begin{array}{l}\text { Patient had alsoPE } \\
\text { Patient had DVT } \\
\text { Patient had DVT+PE; } \\
\text { The three cases were siblings }\end{array}$ \\
\hline $\begin{array}{l}\text { Girolami, et al. } \\
2018(11)\end{array}$ & M, 53 & 1 & 90 & Comp Het. & Severe & Hypercolesterolemia & none & $\begin{array}{l}\text { T insertion, }+ \text { Asp558Glu mutation; DVT. } \\
\text { A brother had two M.I. }\end{array}$ \\
\hline
\end{tabular}

$\mathrm{DVT}=$ deep vein thrombosis; $\mathrm{PE}=$ pulmonary embolism; Hom=homozygote; References number between parenthesis.

\section{Conflicts of interest}

The authors declare that they have no conflict of interest.

\section{References}

1. Colman RW, Marder VJ, Clowes AW, George J, Goldhaber S (2010) Contact activation (kallikrein-kinin) pathway: multiple physiologic and pathopysiologic activities. In: Hemostasis and Thrombosis (5th Edition). Lippincott Williams and Wilkins, PA, USA pp: 107-130.

2. Girolami A, Scarparo P, Candeo N, Lombardi AM (2010) Congenital Prekallikrein deficiency. Exp Rev Hematol 3: 685-695. [Crossref]

3. Moore GW, Sangle SR, Archer RA, Maloney JC, Rahman A, et al. (2014) Complete prekallikrein deficiency masquerading as a lupus anticoagulant. Thromb Res 133: 301302. [Crossref]

4. Baker SM, Kiefer A, Carollo DS, Warrier RP (2018) Prolonged Activated Clotting Time Immediately Prior to Open Cardiac Surgery. Ochsner J 18: 423-424. [Crossref]

5. Girolami A, Rolland C, Sexton D, Vardi M, Bernstein JA (2020) Long-term safety outcomes of prekallikrein (Fletcher factor) deficiency: A systematic literature review of case reports. Allergy Asthma Proc 41: 10-18. [Crossref]

6. Ryu S, Gu JY, Hong KT, Han DH, Kim HK (2019) The First Case of Congenital Prekallikrein Deficiency in Korea With a Novel Pathogenic Variant (c.1198G>T). Ann Lab aMed 39: 229-231. [Crossref]

7. Dasgupta SK, Rivera S, Thiagarajan P (2020) Lisinopril-Induced Angioedema in a Patient with Plasma Prekallikrein Deficiency. TH Open 4: e33-e35. [Crossref]

8. Yasin H, Jamil MO, Williams Iii LA (2020) Diagnostic Pearls and Clinical Implications of Prekallikrein Deficiency. Cureus 12: e8349. [Crossref]

9. Zhou K, Mehedint D, Khadim H (2019) Prolonged activated partial thromboplastin time due to plasma prekallikrein deficiency: a case study and literature review on its clinical significance. Blood Coag Fibrin 30: 300-303. [Crossref]

10. Girolami A, Allemand E, Bertozzi I, Candeo N, Marun S, et al. (2010) Thrombotic events in patients with congenital prekallikrein deficiency: a critical evaluation of all reported cases. Acta Haematol 123: 210-214. [Crossref]
11. Girolami A, Ferrari S, Cosi E, Sambado L, Girolami B (2015) Prevalence of hypertension and its complications in congenital prekallikrein deficiency: analysis of all reported cases and clinical significance. Blood Coagul Fibrinolysis 26: 560-563. [Crossref]

12. Girolami A, Marun SG, Vettore S (2010) A large family from Argentina with prekallicrein deficiency due to a compound heterozygosis ( $\mathrm{T}$ insertion in intron 7 and Asp558Glu in exon 15): prekallikrein Cordoba. Am J Hematol 85: 363-366.

13. Goodnough LT, Saito H, Ratnoff OD (1983) Thrombosis or myocardial infarction in congenital clotting factor abnormalities and chronic thrombocytopenias: a report of 21 patients and a review of 50 previously reported cases. Medicine (Baltimore) 6: 248255. [Crossref]

14. Girolami A, Ferrari S, Cosi E, Girolami B (2020) Increased prevalence of reported cases of congenital prekallikrein deficiency among African Americans as compared with the general population of the United States. Clin Appl Thromb Hemost 26: 1-3. [Crossref]

15. Mendy VL, Vargas R, Payton M, Sims JN, Zhang L (2019) Trends in the Stroke Death Rate Among Mississippi Adults, 2000-2016. Prev Chronic Dis 16: E21. [Crossref]

16. Waldron FA, Benenson I, Jones-Dillon SA (2019) Prevalence and risk factors for hypertensive crisis in a predominantly African American inner-city community. Blood Press 28: 114-123. [Crossref]

17. Colantonio LD, Monda KL, Rosenson RS (2019) Characteristics and Cardiovascular Disease Event Rates among African Americans and Whites Who Meet the Further Cardiovascular Outcomes Research with PCSK9 Inhibition in Subjects with Elevated Risk (FOURIER) Trial Inclusion Criteria. Cardiovasc Drugs Ther 33: 189-199. [Crossref]

18. Ragni MV, Lewis JH, Hasiba U, Spero JA (1980) Prekallikrein (Fletcher factor) deficiency in clinical disease states. Thromb Res 18: 45-54. [Crossref]

19. Quail MT (2013) Prekallikrein deficiency. J Pediatr Oncol Nurs 30: 198-204. [Crossref]

20. Lu X, Zhao W, Huang J (2007) Common variation in KLKB1 and essential hypertension risk: tagging-SNP haplotype analysis in a case-control study. Hum Genet 121: 327-335. [Crossref]

Copyright: (C2020 Girolami A. This is an open-access article distributed under the terms of the Creative Commons Attribution License, which permits unrestricted use, distribution, and reproduction in any medium, provided the original author and source are credited. 